bonds of Is. each, the interest upon which will be found in the enrichment of the whole life of the people served by the work of the University. The faculty of technology carried on in the Municipal College of Technology is also issuing an appeal for I50,00ol., more than half of which has already been subscribed, for the extension of its building and for new equipment. The great and lasting benefit of the work of the University ought to rouse the active sympathy of the numerous municipalities and district councils, together with that of the County Council itself, and to induce these bodies to levy a rate which, if as low as $\frac{1}{2} d$. in the pound, would annually produce a sum equal to the interest upon the half-million it seeks to raise.

\section{Courses on the History of Science.}

G

RMAN and American universities long ago recog. nised the importance of the history of science as a subject of academic study. In British universities the subject is only just beginning to receive attention. In the University of London last year the Faculty of Arts passed a resolution in favour of including the history of science among the subjects for the B.A. degree, and, although the Senate has not yet dealt with the question, the inclusion of the subject in the curriculum for the new diploma in journalism has helped to advance matters. University College undertook to provide the necessary courses. During the first and second terms of the session $1919-20$ Dr. Wolf delivered a course of elementary lectures on the general history and development of science until the end of the eighteenth century. During the present (summer) term Sir W. H. Bragg and others will deal with the history of physical science during the nineteenth century, and Dr. Singer will lecture on the history of medicine. A more elaborate programme will be provided next session. Sir W. H. Bragg and Dr, Wolf will repeat their courses, Prof. J. P. Hill and Dr. Singer will deal with the history of the biological and medical sciences, Prof. Filon will lecture on the history of astronomy, and Mr. Wren on the history of mathematics. The history of other sciences will also be dealt with as opportunity offers.

The primary aim of the elementary courses on the history of science is to provide an essential part of the history of culture. The modern treatment of history is marked by the attention paid to the daily life and habits of the people, as well as to the romance of Court life and the adventures of warriors. The kind of houses which our forefathers inhabited, the kind of dress they wore, and similar matters are receiving due attention in order to fill in the historic picture. All this is as it should be, but the picture can scarcely be complete without the realisation of the mental make-up of the ages, especially so in view of the important role played by scientific ideas in carrying forward the torch of civilisation.

Over and above its value as an essential part of human history, a course on the history of science should also have the moral and disciplinary value of inculcating a scientific frame of mind-the kind of attitude on which the future of mankind will depend more than ever now that the age of faith seems to be a thing of the long ago.

Such are some of the benefits that may be expected even by those who are not, and do not intend to be, scientific workers, to say nothing of the scientific knowledge which even such students are bound to acquire in following an elementary course on the NO. 2635 , VOL. IO5] history of science. More advanced courses for scientific students can scarcely fail to confer the additional advantage of illuminating the methods and results of the makers of science, and so stimulating the latent originality of the student of science.

\section{Marine Biological Structures and Functions.}

VOL. XIII. of Papers from the Department of Marine Biology of the Carnegie Institution of Washing. ton, which has lately reached us, contains some contributions of considerable interest. Dealing with gland-cells of internal secretion in the spinal cord of the skates, C. C. Speidel describes large irregular cells of peculiar structure present to the number of some hundreds in the anterior horn. The nucleus is lobular and branched, and the cytoplasm of the resting cell is homogeneous, but in active stages granules of a protein substance are formed in it and discharged into the tissues of the spinal cord, where they persist for some time. These cells develop from neuroblast tissue, and cells homologous with them have been found in various other fishes. The author discusses their function, and concludes that they are gland-cells of internal secretion. He is unable to find that they are necessary to the life of the skate, or to show what their function may be. In a paper on the spermatophores of Octopus americana, G. A. Drew shows that these structures, while they are built on a similar plan to those of the squid, are adapted to act quite differently, being less complicated, under less tension, and suited for less rapid service, in correspondence with the less active life of the species: H. L. Clark finds in the distribution of littoral Echinoderms of the West Indies evidence of a much closer relationship between that region and the western coast of tropical America than between it and the Mediturranean, while the fauna of Tobago contains an e'ement derived from the Brazilian coast. Studies on the chemistry of light production in luminous organisms by $\mathrm{E}$. N. Harvey reveal that the substance formerly called photophelein by that author includes two bodies, one-luciferin-oxidisable by luciferase with production of light and formation of oxvluciferin, which can again be reduced to luciferin, the other-protophelein proper-assisting in the promotion of the luciferin-luciferase reaction. E. W. Gudger describes the ovary of Felichthys felis, the gaff-topsail catfish, the male of which carries the eggs and larvæ in his mouth.

\section{The Propagation of Flame in Gaseous Mixtures.}

A LTHOUGH the large-scale experiments for which $A$ the Home Office Experimental. Station at Eslzmeals was designed have been discontinued since the outbreak of the war, the laboratories have continued to do good work under the direction of Dr. R. V. Wheeler, the chief chemist. In addition to Dr. Wheeler's own researches on the initiation of flame and its propagation through gaseous mixtures, Mr. W. Payman, a member of his staff, has recently published in the Journal of the Chemical Society a series of papers on the propagation of flame in complex gaseous mixtures (vols. cxv. and cxvii.).

$\mathrm{Mr}$. Payman has determined the upper and lower "limits" of methane that will just propagate a flame along a horizontal glass tube $2.5 \mathrm{~cm}$. in diameter when mixed with an atmosphere containing oxygen and nitrogen in which the oxygen varies from 13.7 to Ioo per cent. He finds the speed of such flames 
almost identical, on the average $20 \mathrm{~cm}$. per $\mathrm{sec}$, the highest speed being measured when the oxygen was $2 \mathrm{I}$ per cent. as in air. The same speed was found for the "lower-limit" mixture of all the other paraffin vapours up to pentane when mixed with air.

The "lower-limit" speed of carbon monoxide is also the same, but with hydrogen and air the speed at the lower limit is much slower (10 cm. per sec.), probably on account of the small size of the flame, which does not nearly fill the tube, though it travels to the end.

Mr. Payman next measured the speed of the uniform rate of the hydrocarbons from methane to pentane (when added in different proportions to air) along the same horizontal glass tube. The fastest uniform rate for methane was given by the mixture containing 9.52 per cent. of methane, viz. $66.6 \mathrm{~cm}$. $/ \mathrm{sec}$. For propane, butane, and pentane the fastest rate was in each case between $82 \mathrm{~cm}$. and $83 \mathrm{~cm}$. per sec.

Then, by mixing together mixtures of the several paraffins which had the same speed, it was shown that all the mixtures had the same speed except just near the maximum or the extinction point, and this gives us a simple means of calculating the values for anv combination of paraffins in air.

In a third paper the speeds of the uniform movement in mixtures of carbon monoxide and air are recorded. The rate increased as the amount of watervapour rose, e.g. when a mixture in equal volumes was saturated with steam at $10^{\circ} \mathrm{C}$. The rate was $60 \mathrm{~cm} . / \mathrm{sec}$, and when saturated at $17^{\circ} \mathrm{C}$. $79 \mathrm{~cm} . / \mathrm{sec}$. The mixture in equal volumes also gave the quickest speed at constant temperature, although the percentage for complete combustion is only 29.5 per cent. The uniform speeds for different mixtures of carbon monoxide with hydrogen and with methane were also determined and compared with the calculated speeds.

In the concluding paper Mr. Payman describes his experiments on the uniform rate of flame in mixtures of methane and of hydrogen with atmospheres richer in oxygen than ordinary air. When methane is mixed with pure oxygen the mixture which gives the fastest initial rate is the theoretical mixture for complete combustion with 33 per cent. of methane to 66 per cent. of oxygen; whereas in the propagation of the explosion-wave the fastest mixture is that in which the gases are in equal volumes. Although the uniform movement of flame in the mixture containing 33 per cent. of methane is faster than that in a mixture containing more methane, the author's photographs show that the explosion-wave is more quickly sef up in the latter. The abrupt physical change in the mode of propagation seems to be accompanied by an abrupt change in the chemical reaction.

These papers form an interesting contribution to our knowledge of the propagation of flame by "conduction."

\section{University and Educational Intelligence.}

EdINBURGH.-His Majesty the King has graciously consented to lay the foundation-stone of the University buildings on the new site of II $_{5}$ acres at Craigmillar on the occasion of the Royal visit to Edinburgh in July next.

Acting on the recommendation of a special committee recently appointed to consider the question of the German chair, the University Court has resolved that no person be appointed professor of German who is not of British nationality and British parentage, and that, in view of the special circumstances of the case, no appcintment to the chair be made at present, but that the present lecturer be retained.

Dr. G. L. Malcolm Smith has been appointed as NO. 2635 , VOL. IO5] whole-time assistant in clinical medicine, and $\mathrm{Mr}$ John Anderson as lecturer in logic and metaphysics.

Dr. Robert Kidston has presented to the geological department a collection of Mesozoic fossil plants. The forestry department has received from the Director of the Royal Scottish Museum, on loan, a collection of forestry exhibits, and from the Forest Research Officer of the Federated Malay States and the Chief Conservator of Forests, Dominion of Canada, prepared samples of commercial woods peculiar to these countries.

Prof. H. J. W. Hetherington, of the University College of South Wales, Cardiff, has been appointed to the principalship of Exeter University College in succession to Mr. A. W. Clayden, resigned.

Noт1ce is given by the Royal College of Physicians of London that the next examination for the Charles Murchison scholarship in clinical medicine will be held on Monday, June i4, and following days. The scholarship is of the value of twenty guineas, and tenable for one year. Intending candidates must send their names and other specified particulars by June $I$ to the Registrar of the College, Pall Mall East, S.W.I.

AT the request of the Ministry of Labour, and with the co-operation of the Rubber Growers' Association, a six months' course of training in the appropriate sciences has been arranged at Birkbeck College to enable ex-Service men to obtain the requisite knowledge to fit them for positions on the great rubber and tea plántations. The course includes training in chemistry, botany, geology, entomology, and simple mechanics, with some knowledge of the care of machinery and book-keeping.

The League of Nations Union is organising a summer school, to be held at Kempsey School, near Worcester, from Saturday, July 3I, to Saturday, August 7. The school is open to both men and women. Applications for admission, which will be considered in the order in which they are received, must reach the League of Nations Union, 22 Buckingham Gate, S.W.I, by June I5. The main object of the summer school is to train those likely to make efficient leaders of study circles.

THE London County Council will shortly proceed to the appointment of the principals of its first group of twenty-two compulsory day continuation schools to be established under the Education Act, 1918. These appointments will be the first of their kind in London, and will be of more than ordinary interest. The type of pupil to be dealt with is one that hitherto has, for the most part, failed to take advantage of educational facilities after leaving the elementary schools. The Act makes great demands on the commercial and industrial world, and it will devolve on the principals of these schools to cultivate close relations with business men and employers, and to secure their cordial co-operation. The success of this great new experiment in national education depends in considerable measure on the sympathy and assistance of the business world. The position of principal will require of its holder administrative ability, good scholastic attainments, and marked personality. The outside-school activities will have to be fostered in every way, so that, with shorter hours of labour, the increased leisure mav be utilised to the fullest profit, not only of the individuals, but also of the community. The work should make a strong appeal to those interested in the social welfare side of education. Advertisements inviting applications for these positions are now appearing in the public Press, and forms of applica- 